\title{
GETEOV KRALJ U TULI U NASTAVI NEMAČKOG JEZIKA: PRIMER DIDAKTIZACIJE KANONSKOG TEKSTA ${ }^{1}$
}

\begin{abstract}
APSTRAKT: Prilikom uvođenja književnosti u nastavu nemačkog jezika, često se prednost daje savremenim tekstovima zbog njihove veće tematske, stilske i jezičke pristupačnosti u odnosu na kanonske tekstove. Bavljenje kanonskom književnošću, međutim, doprinosi sticanju kulturnih i istorijskih znanja, podstiče razvoj estetske kompetencije, kao i lični razvoj. Pomenuta književna dela poseduju izrazitu estetsku vrednost, obrađuju univerzalne teme i prikazuju bezvremene istine. Ovaj rad se bavi rezultatima istraživanja, sprovedenog među učenicima druge godine gimnazije „Svetozar Marković” u Novom Sadu, koji su učestvovali u oglednom času posvećenom obradi balade Kralj u Tuli (Der König in Thule) Johana Volfganga Getea, u kom je primenjen petofazni didaktički model Neve Šlibar. Cilj istraživanja je ispitivanje mogućnosti obrade teksta iz književnog kanona 18. veka u nastavi nemačkog jezika.
\end{abstract}

Ključne reči: književni kanon, Johan Volfgang Gete, Kralj u Tuli, nastava nemačkog jezika i književnosti.

\section{GOETHE'S THE KING IN THULE IN TEACHING GERMAN LANGUAGE: AN EXAMPLE OF A TEACHING APPROACH TO CANONICAL TEXTS}

ABSTRACT: When it comes to introducing literary texts in teaching German as a foreign language, the works of contemporary literature are being favoured over canonical texts for their current themes, style and modern language. However, the study of classical literature contributes to the acquisition of cultural and historical knowledge, the development of aesthetic competence and to personal growth, as these pieces of literature possess a high aesthetic quality, deal with subjects of universal importance and portray timeless truths. This paper presents the findings of a research study conducted among second-year-students of the Svetozar Marković grammar school in Novi Sad, who participated in an experimental class dedicated to teaching Johann Wolfgang Goethe's ballad The King in Thule (Der König in Thule), which involved the implementation of Neva Šlibars five-phases-model. The aim of this research is to test

\footnotetext{
${ }^{1}$ Tekst je proizišao iz seminarskog rada na doktorskim studijama Jezika i književnosti na Filozofskom fakultetu u Novom Sadu iz predmeta Metodika nastave nemačke književnosti kod prof. dr Nikoline Zobenice.
} 
the possibilities of teaching canonical texts from the $18^{\text {th }}$ century in German as a Foreign Language class.

Key words: literary canon, Johann Wolfgang Goethe, The King in Thule, teaching German language and Literature.

\section{KANONSKI TEKSTOVI KAO IZAZOV NASTAVE STRANOG JEZIKA}

Jedan od najrasprostranjenijih pristupa unutar metodike nastave stranog jezika jeste komunikativni pristup, čija primena u praksi najčešće podrazumeva obradu upotrebnih i stručnih tekstova informativnog karaktera, u cilju osposobljavanja učenika za svakodnevnu komunikaciju na stranom jeziku (Neuner and Hunfeld 1988: 99). Šlibar upućuje na opasnosti marginalizacije književnosti u nastavi stranog jezika, ističući da su učenici uskraćeni za upoznavanje jedne značajne dimenzije strane kulture, time što im je onemogućen dodir sa stilski vrednim književnim delima (Šlibar 2011: 93). Jedan od zadataka nastave stranog jezika, u okviru nastavnog programa za nastavu drugog stranog jezika u gimnazijama, koje propisuje Zavod za vrednovanje kvaliteta obrazovanja i vaspitanja, formuliše se na sledeći način: „da učenici upoznaju tekstove iz književnosti određenog jezika koji su pogodni za tumačenje na stranom jeziku i koji omogućavaju interaktivne procese" (Nastavni program za drugi strani jezik: 2011), čime se ističe značaj književnosti u nastavi. Pritom se, međutim, ne preciziraju kriterijumi za izbor književnog teksta za obradu tokom nastavnog procesa. U okviru svojih kriterijuma za izbor književnog teksta, Šlibar, između ostalog, navodi i estetsku vrednost dela, vodeći se time, da je vreme za obradu književnih tekstova u nastavi nemačkog jezika ionako isuviše ograničeno da bi se posvetilo delima niže estetske vrednosti. Siguran izbor predstavljaju ona književna dela koja se smatraju delom književnog kanona (Šlibar 2011: 96).

Polazeći od značenja „merodavan, uzoran izbor iz postojećeg” sadržanog u samom pojmu kanona, književni kanon podrazumeva korpus književnih dela koje data književna zajednica u određenom trenutku procenjuje kao tekstove visoke, neprolazne, reprezentativne i (relativno) neoborive estetske vrednosti (Beli-Genc 2007: 92). Kanon predstavlja značajnu instituciju za građenje nacionalnog kulturnog identiteta i sastavni deo kolektivnog kulturnog pamćenja, koji ,tematizuje i kondenzuje kulturu jedne grupe ili nacije" (Beli-Genc 2007: 94), što ukazuje na značaj obrade ovakvih tekstova, kako bi se učenicima omogućio što celovitiji uvid u nemačku kulturu. Međutim, fiksni književni kanon o kom vlada opšta saglasnost ne postoji, te je njega jedino moguće (re)konstruisati na osnovu prisustva književnih tekstova i komunikacije o njima u različitim kulturno relevantnim institucijama, koje imaju posredničku ulogu u recepciji književnosti, kao i u medijima (Beli-Genc 2007: 94). Iz toga sledi da nastavnicima ne stoji na raspolaganju jedna jedinstvena lista dela kanona nemačke književnosti - naprotiv, postoji bezbroj različitih lista "obaveznih" dela koje su objavljene u Nemačkoj i koje se predstavljaju kao merilo 
školskog, univerzitetskog obrazovanja ili čak opšte kulture, dok se istovremeno u jeku aktuelne diskusije o kanonu, dovodi u pitanje njegova smislenost.

Šlibar takođe navodi da je prilikom izbora književnog teksta za nastavu stranog jezika, potrebno uzeti u obzir njegovu dužinu i aktuelnost, ali i uzrast učenika, njihove jezičke kompetencije i njihova interesovanja (Šlibar 2011: 93-97). Navedeni kriterijumi ukazuju na niz prednosti obrade dela savremene književnosti, koji ne samo da se bave sadašnjicom i aktuelnim temama, već ujedno važe i za jezički pristupačnije u odnosu na kanonske tekstove. Kada je reč o interesovanju učenika, u korist savremenim književnim tekstovima govori podatak, da većina učenika radije čita dela koja su im vremenski, tematski i stilski bliža, što se pozitivno odražava na njihovu motivaciju za čitanje i učenje (Zobenica and Pajić 2013: 247). Poteškoće koje nastaju prilikom obrade kanonskih tekstova proizilaze iz vremenske distance u odnosu na vreme nastanka dela, koja je neophodna za praćenje toka njegove recepcije i za svrstavanje u književni kanon (Paefgen 2006: 55). Sa većom vremenskom distancom ujedno se povećava i distanca u tematskom i jezičkom pogledu, tako da se tekstovi iz 18 . veka smatraju problematičnijim za tematisanje $u$ nastavi u odnosu na tekstove sa početka 20 . veka. Sa druge strane, $u$ prilog obradi kanonskih dela navode se neprolazne vrednosti koje oni sadrže, kao i njihove univerzalne teme koje dotiču čitavo čovečanstvo. Bavljenje kanonskom književnošću podrazumeva sticanje vrednih znanja o istoriji i specifičnostima druge kulture, i pozitivno se odražava na razvoj estetske kompetencije kod učenika, kao i na njihov lični razvoj.

Sa ciljem ispitivanja Šlibarine teze - da je pažljivo osmišljenom didaktizacijom moguće prevazići pomenute probleme prilikom obrade starijih kanonskih književnih dela - za temu oglednog časa odabrana je balada Kralj $u$ Tuli (Der König in Thule) Johana Volfganga Getea iz 1774. godine, koja se pojavljuje i u prvom delu njegove drame Faust. Pripadnost Johana Volfganga Getea kanonu nemačke književnosti, kao i estetska vrednost njegove drame Faust, je i dalje gotovo neosporiva, o čemu između ostalog, svedoči velika zastupljenost navedene drame u različitim listama kanonskih književnih dela. Tako se Faust nalazi i na rigoroznom spisku od tek dvanaest dela celokupne svetske književnosti autora Hara Miler-Mihaelsa (Harro Müller-Michaelsa) iz 1982. godine (Paefgen 2006: 56-57) i $\mathrm{u}$ izboru Kanona nemačkih dela vrednih čitanja (Kanon lesenswerter deutschsprachiger Werke) književnog kritičara Marsel Rajh-Ranickija (Marcel Reich-Ranicki) (Reich-Ranicki: 2001). Centralne teme izabrane balade, ljubav i smrt, bezvremene su i kao takve određuju čovekovo iskustvo od pamtiveka do današnjice. Uprkos tuzi kojom je protkana balada, u njoj je izrečeno i „nešto što okrepljuje srce, nešto toplo o životu" (Korff 1958: 95), što Korf ističe kao najveću vrednost ove ,pesme koja odiše najvećom željom za životom” (Korff 1958: 95). U baladi se oslikava najsvetliji primer potpune i bezuslovne odanosti, dok se ljubav prikazuje kao najveće nematerijalno bogatstvo, koje je značajnije od bilo kakvog materijalnog poseda. Tematski gledano, ova Geteova balada je prikladna za uzrast od 8. razreda nadalje, jer se u toj razvojnoj fazi budi interesovanje za refleksije o 
prirodi života, ljubavi i sopstvenom identitetu (Leubner, Saupe and Richter 2010: 112). Ako se $\mathrm{k}$ tome uzme u obzir i vremenska ograničenost školskog časa i Šlibarino protivljenje obradi isečaka iz književnih dela (jer ona smatra da je za potpuno razumevanje književnog dela neophodno da se ono sagleda u celini (Šlibar 2011: 86)), ova Geteova balada se sa svojih šest katrena i u tom pogledu pokazuje kao pogodna za obradu u nastavi nemačkog jezika. Međutim, uprkos naizgled jednostavnom jeziku balade, koji podseća na narodno pesništvo, ona sadrži arhaične reči i izraze, koji mogu biti veoma problematični, naročito kada je u pitanju nastava nemačkog kao drugog stranog jezika. Didaktizacija balade se samim time suočava sa dva velika izazova: pravilnim razumevanjem dela na jezičkom nivou i motivacijom učenika za bavljenje tekstom iz dalekog 18. veka. Sledeće poglavlje ovog rada posvećeno je opisu pojedinih koraka u didaktizaciji Geteovog Kralja $u$ Tuli, u okviru koje je primenjen petofazni model nastave koji je razvila Neva Šlibar.

\section{DIDAKTIZACIJA GETEOVE BALADE KRALJ U TULI}

Pre davanja detaljnijeg uvida u pojedine faze unutar postupka didaktičkometodičke obrade Geteovog Kralja u Tuli, važno je navesti osnovna pravila koje Šlibar postavlja govoreći o nastavi nemačke književnosti. Naglašavajući značaj nastave književnosti za sticanje ne samo određenih književnih, već i životnih kompetencija, ona u središte nastave stavlja doživljaj književnosti, koja samim tim ne sme da služi kao instrument za obradu gramatičkih jedinica ili sticanja konkretnih znanja o zemljama nemačkog govornog područja (Šlibar 2011: 73). Iz toga sledi da se u takvoj nastavi po principu „književnost radi književnosti” uvežbavanje pojedinih jezičkih veština (čitanje, pisanje, slušanje, govor) posmatra tek kao pozitivan sporedni efekat nastavnog procesa, a ne kao njegov primaran cilj. U opšte ciljeve nastave nemačke književnosti Šlibar ubraja razumevanje književnog teksta kroz njegovu analizu i interpretaciju, kao i osposobljavanje učenika da samostalno čitaju književna dela na nemačkom jeziku (Šlibar 2011: 53). Nastava književnosti ima nadalje za cilj da produbi uživanje prilikom čitanja i da podstakne želju za čitanjem. Početna nelagodnost koju učenici osećaju kada se susreću sa kompleksnim književnim delom iz prošlosti je, po mišljenju Šlibar, moguće prevazići kreativnom nastavom u koju su učenici maksimalno uključeni.

Prilikom didaktizacije Geteove balade Kralj $u$ Tuli primenjen je Šlibarin petofazni model nastave uz pojedina manja odstupanja, koja se smatraju neophodnim za primenu tog modela u nastavi nemačkog kao drugog stranog jezika. Važno je napomenuti da informacije, koje se tiču socijalno-kulturnog ili istorijskog konteksta dela, biografije autora ili pripadnosti teksta određenoj epohi unutar istorije nemačke književnosti, nisu tematizovane na času, jer takvo kontekstualno znanje nije procenjeno kao neophodno za razumevanje sadržine balade.

Prva faza nastave ima, s jedne strane, cilj da kroz uvod u tematiku dela, koje će se obrađivati, podstakne motivaciju kod učenika, dok, s druge strane, ona služi i rasterećenju, koje Šlibar određuje kao stvaranje vedre, opuštene i kreativne 
atmosfere koja je pogodna za učenje (Šlibar 2011: 76). Iako je stvaranje takve klime u učionici od velikog značaja za efikasnost nastavnog procesa, kod nastave stranog jezika na nižem jezičkom nivou potrebno je za cilj postaviti i rasterećenje sadržaja teksta na jezičkom planu. Tu se podrazumeva objašnjavanje ključnih reči iz književnog teksta, sa namerom da se učenicima olakša njegovo razumevanje. Šlibar se suštinski ne protivi takvom pristupu, ali se u prvu ruku zalaže za dugoročniju jezičku pripremu, koja dovodi do toga, da su u trenutku obrade teksta vokabular i gramatičke konstrukcije iz teksta učenicima već unapred poznate (Šlibar 2011: 78), što nije bilo izvodljivo kod ovog oglednog časa. Imajući navedene ciljeve u vidu, na tablu je postavljen pano (Slika 1), na kom su grupisane neke ključne reči oko glavnog lika balade, kralja u Tuli, dok su značenja tih reči ilustrovana slikama. Na osnovu informacija o kralju koje se nalaze na panou, učenici su u plenumu davali pretpostavke o ličnosti kralja i o radnji balade.

Šlibar kao drugu fazu nastave uvodi predstavljanje teksta, naglašavajući značaj prvog kontakta sa delom, u vidu njegovog čistog, čulnog doživljaja, kog ne smeju ometati dodatni zadaci uz slušanje (Šlibar 2011: 76). U oglednom času je nastavnica, nakon što je prethodno izražajno pročitala baladu, podstakla učenike da verbalizuju svoje prve emocionalne utiske o delu uz pomoć pitanja poput: Kako ti se čini balada? Kako se osećaš pošto si je čuo/la? Kako bi je ukratko opisao/la? Učenici su pokazali spremnost da aktivno učestvuju u ovoj fazi obrade teksta.

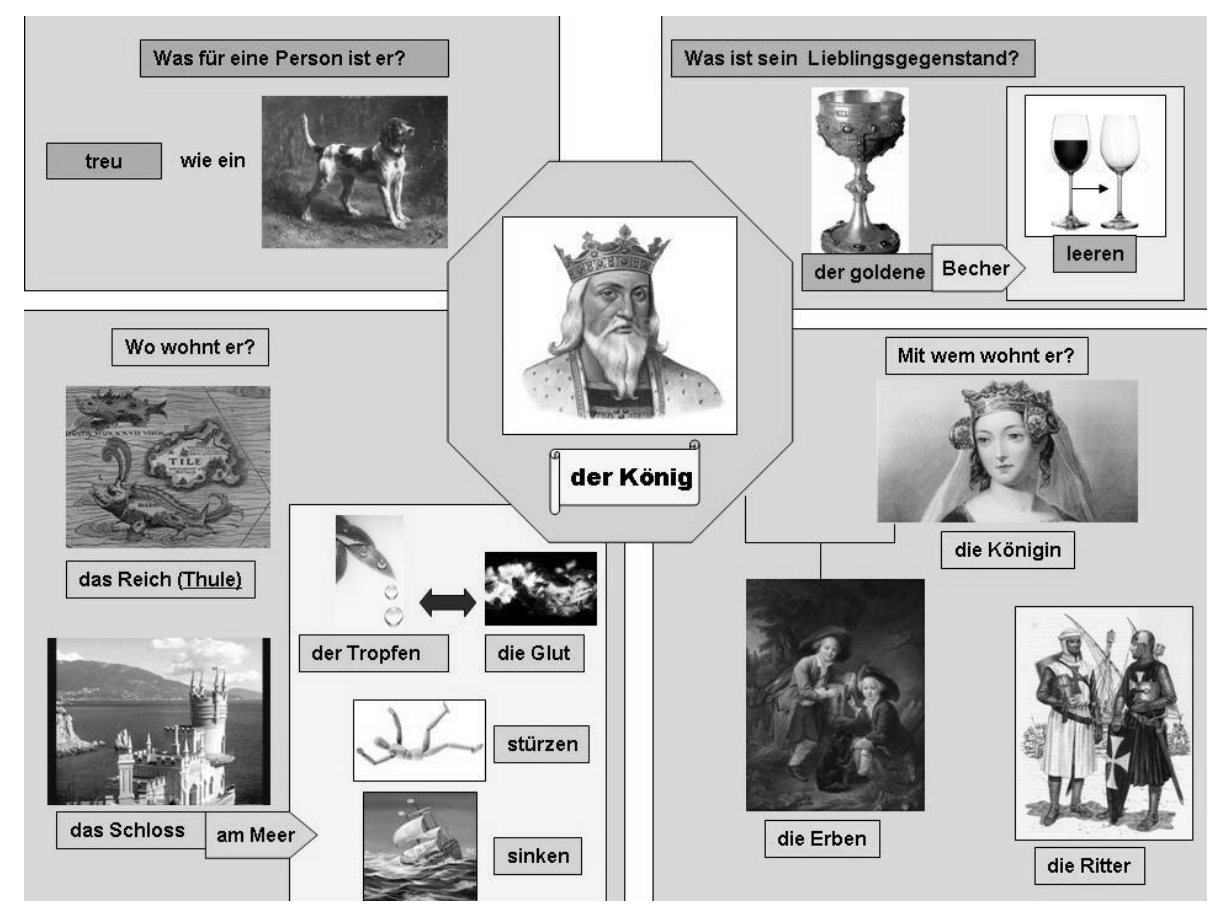

Slika 1. Pano sa ključnim rečima 
Treća faza se odnosi na rad na samom književnom tekstu i sastoji se iz jedne podfaze posvećene globalnom razumevanju i druge posvećene detaljnom razumevanju, na koju se nadovezuje rad na interpretaciji dela. Učenici su dobili tekst balade i zadatak u kom su se, u paru, odlučili za jedan od ponuđenih odgovora na postavljena pitanja. Pitanja se odnose na glavni tok radnje, tako da su učenici pokazali da li su tekst razumeli u osnovnim crtama. Izvesno odstupanje od primenjenog modela predstavlja navođenje kratkih objašnjenja ili sinonima za arhaične reči, datih u vidu fusnota uz tekst balade koji je podeljen učenicma ${ }^{2}$. To su reči za koje je objašnjenje neophodno za pravilno i potpuno razumevanje teksta, a nastavnica je pritom naglasila učenicima da su te reči zastarele i da se ne koriste $u$ svakodnevnom govoru. Vokabular predstavljen na panou čine samo reči koje su i dalje u upotrebi, i one su bile učenicima pred očima sve vreme tokom nastavnog procesa. Važno je napomenuti da je u ovoj fazi neminovno došlo do postavljanja pitanja, koja su se odnosila na reči i izraze koji su i dalje bili nepoznati i koje je nastavnica objašnjavala uz pomoć mimike i gestikulacije. Tako je, na primer, bio problematičan izraz iz druge strofe: „die Augen gingen ihm über” sa značenjem „plakati”. Sledila je provera rešenja zadatka, a učenici su pritom objašnjavali, na osnovu kog dela teksta su se odlučili za svoj odgovor. U okviru sledeće faze, u kojoj se proverava detaljno razumevanje teksta, učenici su podeljeni u grupe i svakoj grupi je dodeljena jedna ili u izuzetnim slučajevima, više strofa ${ }^{3}$. Učenici su potom dobili zadatak da glumom, recitovanjem, crtanjem ili na neki drugi kreativni način, predstave datu strofu, tj. date strofe pred odeljenjem. Pri rešavanju zadatka, učenici su pokazali izrazitu kreativnost, time što su oslikavali scene na hameru (dvorac, more, prostorije u dvorcu), i što su pored kartonskih kruna koje su im bile na raspolaganju, koristili dodatne rekvizite poput flašice sa vodom na kojoj su stavili nalepnicu ,der Becher”, kako bi bilo jasno da predstavlja pehar, zatim plaštova koje su napravili od majica za fizičko, i lenjira i trouglova za tablu koje su koristili kao mačeve i štitove. U većini slučaja su se u grupi odlučili da jednom ili više učenika dodele ulogu "naratora" koji recituju pojedinačne stihove, a drugi učenici bi preuzeli uloge kralja, kraljice, vitezova i sluga i pokretima, mimikom i gestikulacijom prikazivali radnju strofe. Između izrecitovanih stihova bi se, sa vremena na vreme, ubacivali komentari i kratki dijalozi figura na sceni, koji su učenici sami sastavljali. Nakon predstavljanja pojedinačne strofe, nastavnica je na nemačkom jeziku vodila kratak razgovor sa učenicima o datoj strofi, o tome šta se dogodilo u njoj, navodeći ih da spoznaju značajne momente, kako bi se osiguralo temeljno razumevanje radnje balade. Na kraju učenicima je data mogućnost da postavljaju pitanja kralju ili naratoru koji su i dalje na sceni, tako da su učenici

\footnotetext{
${ }^{2}$ U fusntama uz tekst balade navedena su sledeća objašnjenja: Buhle = Geliebte; Schmaus = Mahlzeit; Zecher= eine Person, die gern und oft viel Alkohol trinkt.

${ }^{3}$ Razlog tome je pretežno opisni karakter četvrte strofe, koja je stoga pridodata jednoj učeničkoj grupi uz treću strofu.
} 
podstaknuti da nagađaju o motivima kralja. Kreativni zadatak u ovoj fazi nastave služi podsticanju motivacije učenika za razgovor o mogućnostima interpretacije balade u narednoj fazi, i ovaj korak je izuzetno značajan, jer učenici često sprva zaziru od tako složenog vida razgovora na stranom jeziku usled nesigurnosti u svoje jezičke sposobnosti. Željeni ishod ove faze je dakle, da se učenici opuste i osećaju spremnije za pričanje o interpretaciji balade.

Nakon predstavljanja i analiziranja pojedinačnih delova, pristupilo se interpretaciji teksta u celini, i to uz pomoć metode razgovora u kojoj je nastavnica ima ulogu moderatora. Učenicima se pritom ostavlja prostor za sopstvena tumačenja i zaključke, kao i za međusobno sukobljenje mišljenja, dok nastavnica istovremeno upućuje na značajne delove ili elemente balade, da bi se proces interpretacije usmerio i olakšao (Leubner et al. 2010: 155). Ukazano je na bajkovite elemente balade (početak „Es war einmal”, likove, mesto radnje), analizirana su unutrašnja stanja i osećanja kralja, koja se u baladi „pretvaraju u snažne radnje ka spolja" (Kahl 2002: 172) i interpretirana je simbolika pehara kroz baladu (pehar kao poslednji dar preminule drage, simbol neprolazne ljubavi, vernosti, života i životne snage) kao i kraljevog poslednjeg ispijanja i bacanja pehara u vodu. Bilo je reč i o kraljevom vrednovanju ličnog, nematerijalnog bogatstva ljubavnog iskustva naspram materijalnog blaga, kao i o pojedinim hrišćanskim aluzijama (npr. aluzija na poslednju večeru). Potom se poredilo prvobitno shvatanje teksta sa konačnim, nakon čega je sledilo zajedničko sumiranje rezultata interpretacije, čime se ujedno završila sledeća, četvrta faza posvećena proveri i potvrđivanju rezultata.

Kako bi se uspostavio balans u uvežbanim jezičkim veštinama, u petoj i poslednjoj fazi posvećenoj transferu iliti kreativnoj primeni naučenog, učenici su individualno i uz pomoć rečnika, pisali kratku pesmu stroge forme, „Elfchen”, koja se sastoji od $11 \mathrm{reči}^{4}$. U kratkim pesmama predstavili su sopstveni doživljaj dela, osećanja određenog lika ili čak alternativni završetak ili nastavak balade. Forma ove kratke pesme je učenicima već bila poznata, tako da je ukratko ponovljena i ilustrovana nastavničinim primerom. Značajna prednost ove forme je vremenska ekonomičnost, za razliku od opširnijih tekstova poput književne kritike ili intervjua.

$\mathrm{Na}$ kraju oglednog časa, učenicima je podeljen anonimni upitnik za evaluaciju časa, koji se sastoji iz ukupno 23 pitanja. Učenici su upitnik ispunjavali u prisustvu nastavnice, koja im je bila na raspolaganju u slučaju nejasnoća. Predmet analize u narednom poglavlju čine rezultati dobijeni uz pomoć upitnika, na osnovu kojih će se utvrditi uspešnost održanog oglednog časa, kao i tačnost polazne hipoteze.

4 Pesma „Elfchen” se sastoji iz pet stihova. Prvi stih sadrži jednu reč, koja može da označava predmet, boju, ime i slično. U drugom stihu se uz pomoć dve reči opisuje neka radnja, čiji je agens reč iz prvog stiha. U trećem stihu se uz pomoć tri reči opisuje reč iz prvog stiha. U četvrtom stihu se daje utisak ili mišljenje autora, i za to se koriste četiri reči. Peti i poslednji stih predstavlja zaključak, koji se daje uz pomoć samo jedne reči. 


\section{ANALIZA REZULTATA ISTRAŽIVANJA}

Ogledni čas obrade Geteove balade Kralj u Tuli održan je 17. juna 2016. u gimnaziji „Svetozar Marković” u Novom Sadu. U istraživanju je učestvovao 41 učenik drugog razreda opšteg smera. Tog dana je isti čas u trajanju od 45 minuta održan u dva odeljenja - pritom je u jednom odeljenju bilo prisutno 26 učenika, a u drugom odeljenju 15 učenika. Ispitana učenička grupa se sastoji od 15 dečaka i 26 devojčica uzrasta između 16 i 17 godina, koji su u tom trenutku nemački kao drugi strani jeziki učili šest godina. Udžbenik po kojem se do tada odvijala nastava nemačkog jezika je Schritte international 4 nemačke izdavačke kuće Hueber, koji odgovara A2/2 nivou Zajedničkog evropskog okvira za jezike.

U prvom delu upitnika nalazi se 19 tvrdnji, koje su učenici procenjivali korišćenjem petostepene Likertove skale (1 - potpuno se ne slažem, 2 - uglavnom se ne slažem, 3 - i slažem se i ne slažem se, 4 - uglavnom se slažem, 5 - potpuno se slažem). Analiza se bazira na procentualnom prikazu učestalosti učeničkih odgovora. U okviru analize rezultata posmatrane su tri grupe ispitanika: učenici koji su zaokruživanjem opcije 1 ili 2 izrazili neslaganje sa datom tvrdnjom, potom učenici koji su zaokruživanjem opcije 4 ili 5 pokazali da se slažu sa datom tvrdnjom i učenici koji su zaokruživanjem opcije 3 ostali uzdržani.

\begin{tabular}{lccccc}
\hline & $\mathbf{1}$ & $\mathbf{2}$ & $\mathbf{3}$ & $\mathbf{4}$ & $\mathbf{5}$ \\
\hline 1. Volim književnost. & $14,6 \%$ & $4,9 \%$ & $26,8 \%$ & $19,5 \%$ & $34,2 \%$ \\
\hline $\begin{array}{l}\text { 2. Sviđa mi se starija književnost } \\
\text { (19. vek i ranije). }\end{array}$ & $19,5 \%$ & $24,4 \%$ & $39 \%$ & $12,2 \%$ & $4,9 \%$ \\
\hline 3. Uživam u čitanju poezije. & $12,2 \%$ & $24,4 \%$ & $31,7 \%$ & $17,4 \%$ & $14,6 \%$ \\
\hline $\begin{array}{l}\text { 4. Zanimljivo mi je da analiziram i } \\
\text { interpretiram pesme. }\end{array}$ & $7,3 \%$ & $22 \%$ & $31,7 \%$ & $19,5 \%$ & $19,5 \%$ \\
\hline
\end{tabular}

Tabela 1. Stavovi učenika o književnosti

Prve četiri tvrdnje (Tabela 1) služe sticanju uvida u opšte stavove o književnosti ispitane učeničke grupe. Činjenica da se preko polovine ispitanih učenika $(53,7 \%)$ izjašnjava da voli književnost (naspram 19,5\% neistomišljenika), kao i da većina (39\%) smatra analiziranje i interpretiranje pesama zanimljivim (naspram 29,3\% onih koji ne dele isto mišljenje) ukazuje na povoljne preduslove za obradu književnog teksta u nastavi nemačkog jezika. Međutim, analiza učeničke procene druge tvrdnje pokazuje da većina učenika (43,9\% naspram $17,1 \%$ njih) ima odbojan stav prema starijoj književnosti, u koju na osnovu date odrednice 19. vek i ranije, spada i Geteova balada Kralj $u$ Tuli, što je predstavljalo značajan izazov za njenu obradu. Što se tiče treće tvrdnje, većina učenika $(36,6 \%)$ izjasnila se da ne uživa u čitanju poezije, što, uprkos znatnom broju neistomišljenika (32\%), ukazuje na još jednu početnu otežavajuću okolnost za uspešnu realizaciju časa. Kod sva četiri pitanja je nezanemarljiv procenat onih, koji su se odlučili za neutralni 
odgovor, što govori o tome da ti učenici još uvek nemaju izgrađen stav po tim pitanjima.

\begin{tabular}{|c|c|c|c|c|c|}
\hline & 1 & 2 & 3 & 4 & 5 \\
\hline 5. Geteova balada mi se dopala. & $2,4 \%$ & $2,4 \%$ & $19,5 \%$ & $26,8 \%$ & $48,8 \%$ \\
\hline $\begin{array}{l}\text { 6. Balada mi je pri prvom kontaktu bila } \\
\text { potpuno nerazumljiva. }\end{array}$ & $4,9 \%$ & $17,1 \%$ & $31,7 \%$ & $22 \%$ & $24,4 \%$ \\
\hline $\begin{array}{l}\text { 7. Uvodni deo časa mi je pomogao u } \\
\text { razumevanju balade. }\end{array}$ & $2,4 \%$ & $2,4 \%$ & $9,8 \%$ & $12,2 \%$ & $73,2 \%$ \\
\hline $\begin{array}{l}8 \text {. Bilo mi je teško da interpretiram Geteovu } \\
\text { baladu. }\end{array}$ & $58,5 \%$ & $12,2 \%$ & $14,6 \%$ & $12,2 \%$ & $2,4 \%$ \\
\hline 9. Sadržaj Geteove balade mi je dosadan. & $61 \%$ & $14,6 \%$ & $14,6 \%$ & $7,3 \%$ & $2,4 \%$ \\
\hline
\end{tabular}

Tabela 2. Utisci učenika o Geteovoj baladi i njenoj obradi na času

Narednih pet tvrdnji (Tabela 2) odnosi se na učeničke utiske o Geteovoj baladi i o njenoj obradi na času. Uprkos većinskom stavu protiv poezije i književnosti pre 20 . veka, ubedljiva većina $(75,6 \%)$ izjasnila se da im se balada dopala, dok je procenat onih suprotnog mišljenja veoma mali $(4,8 \%)$, što ukazuje da su početne prepreke uspešno prevaziđene kreativnom didaktičkom obradom balade. Većina učenika (46,4\% naspram tek $22 \%$ neistomišljenika) navodi da im je balada pri prvom kontaktu bila potpuno nerazumljiva, dok čak $85,4 \%$ ispitanih učenika (naspram tek $4,8 \%$ neistomišljenika) smatra da im je uvodni deo časa pomogao pri razumevanju balade, na osnovu čega se ta faza oglednog časa može smatrati izuzetno uspešnom. Time se ujedno potvrđuje značaj rasterećenja na jezičkom nivou u okviru uvodne faze obrade književnog teksta $u$ nastavi stranog jezika. To što ubedljiva većina učenika $(70,7 \%)$ navodi da nije imala poteškoće prilikom interpretacije ove Geteove balade, dok je tek 14,6\% učenika suprotnog mišljenja, ukazuje na uspešnost faze rada na tekstu, kao i na mogućnost da se učenicima približi kompleksan književni tekst pažljivom metodičko-didaktičkom obradom. Iako je u pitanju tekst iz dalekog 18 . veka, tek $9,7 \%$ ispitanih učenika je navelo da im je sadržaj Geteove balade dosadan, dok je čak 75,6\% učenika suprotnog mišjenja, čime se iznova povrđuje moć kreativne i dinamične nastave, kojom je moguće nadvladati početne negativne stavove prema tekstu iz tog perioda.

Procenom narednih pet tvrdnji (Tabela 3) učenici se izjašnjavaju po pitanju ishoda časa obrade Geteove balade. Utisak ubedljive većine $(78,1 \%$ naspram tek $4,8 \%$ neistomišljenika), da su puno toga naučili tokom časa, pokazuje da učenici ishod nastave ocenjuju izrazito pozitivno. Isto tako, $56,2 \%$ učenika smatra da je ovaj čas dobro uticao na njihovu sposobnost izražavanja na nemačkom jeziku, što svakako predstavlja značajan i željeni sporedni efekat nastave književnosti, dok se tek $26,9 \%$ ne slaže sa tom tvrdnjom. Većina učenika (41,5\% nasuprot $31,7 \%$ neistomišljenika) navelo je da je nakon oglednog časa njihovo interesovanje za nemačku književnost veće, dok su rezultati procene naredne dve tvrdnje nešto nepovoljniji, kako 41,5\% 
učenika (nasuprot 36,6\% neistomišljenika) želi da čita još pesama na nemačkom, dok je procenat onih učenika koji su izrazili želju da čitaju još pesama od Getea i onih koji to ne žele veoma blizak: $39,1 \%$ nasuprot $36,6 \%$. Ovde se odražava negativan stav prema poeziji kod većine učenika, koji su izrazili odgovorom na treće pitanje. Nezanemarljiv procenat učenika sa neutralnim stavom takođe upućuje na to da, iako je većina u okviru petog pitanja navela da im se dopada Geteova balada, to nije znatno uticalo na njihovu motivaciju za čitanje poezije na nemačkom jeziku.

\begin{tabular}{lccccc}
\hline & $\mathbf{1}$ & $\mathbf{2}$ & $\mathbf{3}$ & $\mathbf{4}$ & $\mathbf{5}$ \\
\hline 10. Puno toga sam naučio/la na ovom času. & $2,4 \%$ & $2,4 \%$ & $17,1 \%$ & $36,6 \%$ & $41,5 \%$ \\
\hline $\begin{array}{l}\text { 11. Sada se lakše izražavam na nemačkom } \\
\text { jeziku. }\end{array}$ & $4,9 \%$ & $21,95 \%$ & $17,1 \%$ & $44 \%$ & $12,2 \%$ \\
\hline $\begin{array}{l}12 . \quad \text { Moje interesovanje za nemačku } \\
\text { književnost je sada jače. }\end{array}$ & $12,2 \%$ & $19,5 \%$ & $26,8 \%$ & $29,3 \%$ & $12,2 \%$ \\
\hline \begin{tabular}{l} 
13. Želim da čitam još pesama na nemačkom. \\
\hline 14. Želim da čitam još pesama od Getea.
\end{tabular} & $12,2 \%$ & $24,4 \%$ & $22 \%$ & $22 \%$ & $19,5 \%$ \\
\hline
\end{tabular}

Tabela 3. Učenička procena ishoda časa obrade Geteove balade

\begin{tabular}{lccccc}
\hline & $\mathbf{1}$ & $\mathbf{2}$ & $\mathbf{3}$ & $\mathbf{4}$ & $\mathbf{5}$ \\
\hline $\begin{array}{l}\text { 15. Želim da češće obrađujemo književnost na } \\
\text { časovima nemačkog. }\end{array}$ & $7,3 \%$ & $2,4 \%$ & $29,3 \%$ & $26,8 \%$ & $36,6 \%$ \\
\hline $\begin{array}{l}\text { 16. Želim da na času nemačkog književnost } \\
\text { obrađujemo češće od dvaput godišnje. }\end{array}$ & $2,4 \%$ & $7,3 \%$ & $12,2 \%$ & $26,8 \%$ & $51,2 \%$ \\
\hline $\begin{array}{l}\text { 17. Uvođenje književnosti bi časove nemačkog } \\
\text { jezika učinilo zanimljivijim. }\end{array}$ & $4,9 \%$ & $4,9 \%$ & $14,6 \%$ & $17,1 \%$ & $58,5 \%$ \\
\hline $\begin{array}{l}\text { 18. Želim da na času nemačkog ponovo } \\
\text { obrađujemo delo koja pripada starijoj } \\
\text { književnosti (19. vek i pre). }\end{array}$ & $4,9 \%$ & $12,2 \%$ & $29,3 \%$ & $34,2 \%$ & $19,5 \%$ \\
\hline $\begin{array}{l}\text { 19. Mislim da bi bilo zanimljivije da na času } \\
\text { nemačkog jezika obrađujemo noviju } \\
\text { književnost (20. vek i kasnije). }\end{array}$ & $7,3 \%$ & $2,4 \%$ & $34,2 \%$ & $29,3 \%$ & $26,8 \%$ \\
\hline
\end{tabular}

Tabela 4. Odnos učenika prema uvođenju književnosti u nastavu nemačkog jezika

Pošto prikazani ogledni čas predstavlja prvi čas obrade književnog teksta za ispitanu učeničku grupu, procenom poslednjih pet tvrdnji (Tabela 4) ispituje se odnos učenika prema uvođenju književnosti u nastavu nemačkog jezika, i ujedno se dobija uvid u to kakve književne tekstove bi učenici voleli da se obrađuju na času. Iako prethodni rezultati ne pokazuju izrazitu motivaciju (ali ni izrazitu nemotivaciju) učenika da se bave nemačkom književnošću, $63,4 \%$ njih je izrazilo želju da se na časovima nemačkog češće obrađuje književnost, dok je protiv toga tek $9,7 \%$ učenika. Čak 78\% ispitanih učenika bi želelo da se književna dela na času nemačkog obrađuju češće od dva puta godišnje nasuprot $9,7 \%$ onih koji se tome protive. Pozitivan stav 
učenika prema književnosti u nastavi nemačkog pokazuje i to, što $75,6 \%$ učenika naspram 9,8\% neistomišljenika smatra da bi uvođenje književnosti učinilo časove nemačkog jezika interesantnijim. Iako se u devetnaestom pitanju preko polovine učenika, tačnije $56,1 \%$ njih naspram tek $9,7 \%$ neistomišljenika, izjasnilo da bi radije obrađivali noviju književnost, čime se potvrđuje teza da većina mladih pokazuje veće interesovanje za novije tekstove koji su im vremenski bliži, u prethodnom pitanju se preko polovine učenika, $53,7 \%$ njih nasuprot $17,1 \%$ neistomišljenika, izjasnilo da bi htelo da se na času nemačkog ponovo obrađuje starije književno delo. Navedeni podaci ipak upućuju na otvorenost i interesovanje učenika za upoznavanje književnosti iz različitih epoha i vremenskih perioda, uprkos početnim negativnim stavovima prema starijoj književnosti.

Rezultati drugog dela upitnika, u kom su učenici ocenili čas određivanjem vrednosti na numeričkoj skali procene od 1 do 7 (pri čemu je 4 neutralna vrednost), ukazuju na izrazito pozitivne utiske učenika. Učenici su procenili da je obrađivanje Geteove balade Kralj u Tuli bilo lako (srednja ocena 5,8 na skali od 1 - naporan do 7 - lak), zanimljivo (srednja ocena 6,4 na skali od 1 - dosadan do 7 - zanimljiv) i korisno (srednja ocena 6 na skali od 1 - beskoristan do 7 - koristan).

Poslednji deo upitnika čine tri pitanja otvorenog tipa, gde se učenicima daje prostor da konkretno navedu šta im se svidelo na času, a šta ne, i da ostave sugestije i komentare. Analiza učeničkih odgovora pokazala je da su se učenicima najviše svideli kreativni zadaci, pogotovo prikazivanje pojedinačnih strofa sa elementima glume, kao i način interpretacije pesme, atmosfera na času, koju su opisali kao opuštenu, zabavnu, povoljnu za učenje, ali i činjenica da su svi bili uključeni u nastavu. Pojedinačni komentari pohvaljuju uvodnu fazu časa kao i samu baladu. Nijedan učenik nije naveo šta mu se nije svidelo na času. $U$ polju za komentare $i$ sugestije, dva učenika su navela da bi voleli da su imali više vremena za kreativne zadatke, dok su učenici često navodili kako bi voleli da se češće održavaju ovakvi časovi.

21. Šta ti se najviše svidelo na današnjem času? (npr. koji zadaci) Obrazloži!

U1: Svi smo učestvovali, drugačije je i opušteno, kroz igru smo uspeli puno toga da naučimo.

U2: Sviđa mi se što smo glumili, bili kreativni. Dopalo mi se kako smo zajednički interpretirali реsти.

U3: Svidela mi se balada i bilo mi je interesantno da je analiziram. Mislim da je čas bio koristan i zanimljiv.

U4: Naučili smo nove reči i zabavili se. Uvod je bio dobar, pomogao mi je da bolje razumem реsти.

U5: Čas je bio podeljen na faze i u svakoj smo bili uključeni. Sve mi se svidelo, bilo je veoma zanimljivo, trebali bismo bar dvaput godišnje da imamo ovakav čas!

U6: Pozitivna atmosfera, dinamičnost, smeh = tako se bolje uči.

Tabela 5. Utisci pojedinih učenika o tome šta im se najviše svidelo na času 


\section{ZAKLJUČAK}

Rezultati istraživanja potvrđuju polaznu hipotezu da je primenom modela nastave koji je razvila Neva Šlibar moguće uspešno savladati početne izazove koje donosi obrada teksta iz književnog kanona 18. veka u nastavi nemačkog kao stranog jezika. Na primeru obrade balade Kralj $u$ Tuli Johana Volfganga Getea po pomenutom modelu dokazano je, da pažljivo promišljena uvodna faza časa, koja uključuje jezičko rasterećenje sadržaja književnog teksta, dovodi do prevazilaženja poteškoća u razumevanju teksta na jezičkom nivou, koje se neretko javljaju prilikom obrade kompleksnog književnog teksta iz 18. veka. Isto tako je dokazano da se kreativnom i dinamičnom nastavom književnosti, u koju su učenici maksimalno uključeni, poništava početna bezvoljnost, koja proizilazi iz nedovoljnog interesovanja za književnost koja im tematski i stilski nije bliska. Na taj način učenici postaju motivisani da se posvete analizi i interpretaciji takvog književnog dela, što im samim time i lakše pada. Iako su učenici u upitniku izrazili veće interesovanje za obradu novijih književnih tekstova, rezultati evaluacije ujedno ukazuju na njihovu novonastalu otvorenost i motivaciju za ponovnim bavljenjem književnim delom koje pripada starijoj književnosti. Taj podatak, kao i izrazito pozitivni učenički stavovi o integrisanju književnosti u nastavu nemačkog jezika, ukazuju na odličnu osnovu za uvođenje časova nemačke književnosti u nastavu nemačkog jezika, u kojoj bi se obrađivala dela iz različitih književnih perioda i epoha.

\section{LITERATURA}

Beli-Genc, J. (2007). "Tema i dilema: kanon”, u XVIII stoleće. VI: „nova viđenja”, ur. N. Grdinić (Novi Sad: Zavod za kulturu Vojvodine): 90-106.

Kahl, J. (2002). "Ein König zieht Bilanz Erworbener und erfahrener Reichtum: Philosophische Meditation zu einem Goethe- Gedicht". Aufklärung und Kritik 2: 171-173.

Korff, H. A. (1958). Goethe: im Bildwandel seiner Lyrik. Bd. 1. Hanau/M: Werner Dausien.

Leubner, M., Saupe, A. and Richter, M. (2010). Literaturdidaktik. Berlin: Akademie Verlag.

Nastavni program za drugi strani jezik (2011). Beograd: Zavod za unapređenje obrazovanja i vaspitanja. Pristupljeno 17.9.2016.

URL: 〈http://www.zuov.gov.rs/poslovi/nastavni-planovi/nastavni-planovi-os-i-ss/>

Neuner, G. and Hunfeld, H. (1998). Methoden des fremdsprachlichen Deutschunterrichts: eine Einführung. Berlin: Langenscheidt.

Paefgen, E. K. (2006). Einführung in die Literaturdidaktik. 2. aktualisierte und erweiterte Aufl. Stuttgart, Weimar: Metzler.

Reich-Ranicki, M. (2001). "Der Kanon. " Pristupljeno 29.4.2018. URL: <http://mreich-ranicki.de/index.php?content=http://m-reichranicki.de/content_themen_kanon.html > 
Šlibar, N. (2011). Wie didaktisiere ich literarische Texte?: neue Maturatexte und viele andere im DaF-Unterricht. Ljubljana: Znanstvena založba Filozofske fakultete.

Zobenica, N. and Pajić, I. (2013). "Deutsche Gegenwartsliteratur im DaF-Unterricht in Serbien", in Treffpunkte: Literatur, Sprache und Didaktik im deutschserbischen Dialog, ed. J. Beli-Göncz, I. Boose and B. Petronijević (Baltmannsweiler: Schneider Verlag Hohengehren): 244-262.

Ivana S. Marinkov

University of Novi Sad

Faculty of Philosophy Novi Sad

$\mathrm{PhD}$ program in Language and Literature

GOETHE'S THE KING IN THULE IN TEACHING GERMAN LANGUAGE: AN EXAMPLE OF A TEACHING APPROACH TO CANONICAL TEXTS

\section{Summary}

When it comes to introducing literary texts in teaching German as a foreign language, the works of contemporary literature are favoured over canonical texts for their current themes, style and modern language. As it takes a certain amount of time for a piece of literature to enter the literary canon, the main concerns are that the students can have a hard time engaging with the subject matter of a text from another era and understanding its complicated language, which is often different from German that is currently being spoken. However, there are also significant benefits to the study of classical literature due to the fact that these pieces possess a high aesthetic quality, deal with subjects of universal importance and portray timeless truths. The study of canonical texts thus contributes to the acquisition of cultural and historical knowledge, encourages the development of aesthetic competence and has a positive effect on personal growth. The goal of the five-phases-teaching-model, which was developed by Neva Šlibar and which is applied in teaching literature in foreign language classes is to to turn the unease that sets in when dealing with a complex literary text into pleasure through exact understanding of the text and productive activities. This paper presents the findings of a research study conducted among second-year-students of the Svetozar Marković grammar school in Novi Sad, who participated in an experimental class dedicated to teaching Johann Wolfgang Goethe's ballad The King in Thule (Der König in Thule), which involved the implementation of the mentioned model by Neva Šlibar. The aim of this research is to test the possibilities of teaching canonical texts from the $18^{\text {th }}$ century in German as a foreign language class. The analysis of the results obtained from an anonymous evaluation questionnaire shows that one is in fact able to overcome the challenges while dealing with a canonical text through a well-thought-out and creative teaching approach.

Key words: literary canon, Johann Wolfgang Goethe, The King in Thule, teaching German language and Literature.

Primljeno: 30. 4. 2018. Prihvaćeno: 28. 7. 2018. 